\title{
PERBEDAAN MODEL PEMBELAJARAN KOOPERATIF TIPE TEAMS GAMES TOURNAMENT DAN MAKE A MATCH TERHADAP HASIL BELAJAR
}

\author{
Erni Fatmawati ${ }^{1}$, Ria Yuliatin ${ }^{2}$ \\ ${ }^{1,2}$ Program Studi Pendidikan TIK IKIP PGRI Pontianak \\ Jalan Ampera Nomor 88 Pontianak \\ ${ }^{1}$ e-mail: ernifatmawati@ikippgriptk.ac.id
}

\begin{abstract}
Abstrak
Tujuan penelitian untuk mengetahui: (1) Rata-rata hasil belajar siswa menggunakan tipe Teams Games Tournament; (2) Rata-rata hasil belajar siswa menggunakan tipe Make a Match; dan (3) Perbedaan rata-rata hasil belajar siswa antara tipe Teams Games Tournament dan Make a Match. Metode penelitian eksperimen dengan bentuk penelitian quasi experimental design. Rancangan non equivalent control group design. Sampel berjumlah 55 siswa. Instrumen penelitian berupa tes pilihan ganda. Analisis data menggunakan analisis deskriptif dan inferensial. Hasil penelitian menunjukkan: (1) Rata-rata hasil belajar siswa menggunakan tipe Teams Games Tournament adalah 79,89; (2) Rata-rata hasil belajar siswa menggunakan tipe Make A Match adalah 84,52; dan (3) Perbedaan rata-rata hasil belajar siswa antara tipe Teams Games Tournament dan Make A Match menunjukkan nilai sig. sebesar 0,048. Dengan taraf kepercayaan 5\% disimpulkan bahwa terdapat perbedaan antara model pembelajaran kooperatif tipe Teams Games Tournament dan Make A Match terhadap hasil belajar siswa.
\end{abstract}

Kata Kunci: Pembelajaran Kooperatif, Tipe Teams Games Tournament, Tipe Make A Match, Hasil Belajar.

\begin{abstract}
The purpose of the study was to find out: (1) The mean score of the students learning outcomes by using Teams Games Tournament; (2) The mean score of the students learning outcomes by using Make a Match; and (3) The difference mean score between Teams Games Tournament and Make a Match. The method used in this research was quasi experimental design. This research was non-equivalent control group design. The sample was 55 students. The research instrument was a multiple choice test. The data were analyzed by using descriptive and inferential analysis. The results showed that: (1) The mean score of the students learning outcomes by using Teams Games Tournament was 79.89; (2) The mean score of the students learning outcomes by using Make a Match was 84.52; and (3) Difference mean score between Teams Games Tournament and Make a Matchwas 0,048 at level significance of 5\%. It was concluded that there was a difference between the cooperative learning models of the Teams Games Tournament and Make a Match on student learning outcomes.
\end{abstract}

Keywords: Cooperative Learning, Type of Teams Games Tournament, Type of Make A Match, Learning Outcomes.

\section{PENDAHULUAN}

Pendidikan adalah salah satu upaya yang dilakukan untuk mewujudkan perubahan sikap dan tingkah laku seseorang. Melalui proses pembelajaran siswa 
menjadi aktif untuk mengembangkan potensi yang ada dalam dirinya. Dalam pendidikan terdapat proses belajar mengajar yang melibatkan siswa dan guru serta semua hal yang ada di lingkungan pendidikan tersebut, baik masyarakat sekolah maupun fasilitas sekolah. Proses belajar mengajar melibatkan dua pelaku aktif, yaitu guru dan siswa. Guru merupakan faktor utama bagi terciptanya generasi penerus bangsa yang berkualitas, tidak hanya dari sisi intelektualitas melainkan juga dari tata berperilaku dalam masyarakat. Peran guru dalam proses kemajuan pendidikan sangat penting karena guru berperan untuk meningkatkan hasil pembelajaran.

Hasil belajar dapat meningkat dan juga dapat menurun dikarenakan banyak faktor yang dapat memengaruhi, seperti model pembelajaran yang diterapkan oleh guru untuk membantu dalam proses pembelajaran. Model pembelajaran adalah suatu pendekatan yang digunakan dalam kegiatan pembelajaran. Menurut Arends (Suprijono, 2013), model pembelajaran mengacu pada pendekatan yang digunakan termasuk didalamnya tujuan-tujuan pembelajaran, tahap-tahap dalam kegiatan pembelajaran, lingkungan pembelajaran, dan pengelolaan kelas. Model yang menyenangkan akan mengurangi rasa bosan siswa ketika dalam proses pembelajaran. Sedangkan model yang kurang tepat diterapkan di dalam kelas akan menyebabkan siswa sulit memahami pelajaran, tidak fokus, dan merasa bosan. Siswa akan merasa ngantuk dan tidak bersemangat selama proses pembelajaran berlangsung. Hal tersebut akan menyebabkan tidak maksimalnya hasil belajar siswa.

Berdasarkan hasil praobservasi di SMP Negeri 5 Sungai Kakap pada semester ganjil tahun 2018, diperoleh beberapa informasi mengenai proses pembelajaran TIK. Proses pembelajaran TIK di SMP Negeri 5 Sungai Kakap yang dilakukan yaitu guru belum menerapkan model-model pembelajaran yang berbeda dan kegiatan-kegiatan yang sifatnya kelompok masih sangat kurang dalam proses pembelajaran. Dengan memberikan model pembelajaran yang tepat dan menyenangkan, dapat memberikan solusi untuk meningkatkan hasil belajar siswa. Siswa dapat lebih aktif di dalam kelas ketika proses pembelajaran berlangsung. 
Model pembelajaran yang dapat digunakan sebagai alternatif adalah model pembelajaran kooperatif tipe Teams Games Tournament dan tipe Make A Match.

Model pembelajaran Teams Games Tournament (TGT) terdiri dari 5 (lima) tahapan yaitu: tahap presentasi kelas (class precentation), belajar dalam kelompok (Team), permainan (Games), pertandingan (tournament), dan penghargaan kelompok (team recognition). Team Games Tournament adalah salah satu tipe pembelajaran kooperatif yang menempatkan peserta didik dalam kelompok belajar yang beranggotakan lima atau enam orang peserta didik yang memiliki kemampuan, jenis kelamin, dan suku atau ras yang berbeda (Rochmanto, 2015).

Kelebihan model kembelajaran kooperatif tipe TGT menurut Susanna (2017), yaitu: (1) Lebih meningkatkan pencurahan waktu untuk tugas; (2) Mengedepankan penerimaan terhadap perbedaan individu; (3) Dengan waktu yang sedikit dapat menguasai materi secara mendalam; (4) Proses belajar mengajar berlangsung dengan keaktifan dari siswa; (5) Mendidik siswa untuk berlatih bersosialisasi dengan orang lain; (6) Motivasi belajar lebih tinggi; (7) Hasil belajar lebih baik; dan (8) Meningkatkan kebaikan budi, kepekaan, dan toleransi. Model pembelajaran TGT merupakan model pembelajaran kooperatif yang berupa permainan dengan menggunakan kuis dalam bentuk pertanyaan yang berkaitan dengan materi pelajaran yang telah disampaikan.

Tiga elemen dasar TGT menurut DeVries dan Slavin (Veloo, dkk., 2016), TGT has three basic elements, namely: (1) teams - students are randomly assigned into teams based on their having similar abilities and they remain in the same team throughout the cooperative learning process. (2) games - students involve in exercises designed by the teacher, and (3) tournament - students represent their teams and compete individually against students from other teams. The individual score contributes to the team's score.

Model pembelajaran TGT memiliki persamaan dengan metode pemebelajaran kooperatif tipe Make A Match. Dapat dipahami bahwa: (1) Model pembelajaran kooperatif tipe Make A Match bertujuan untuk menumbuhkan sikap saling menghormati, menumbuhkan sikap tanggung jawab, meningkatkan percaya 
diri dalam menyelesaikan suatu masalah; (2) Merupakan model pembelajaran yang mengharuskan anak didik aktif dalam pembelajaran, keterampilan keterampilan mulai dari tingkat awal maupun tingkat mahir yang dimiliki anak didik akan terlihat dalam pembelajaran; (3) Lingkungan dalam pembelajaran Make A Match diusahakan demokratis, anak didik diberi kebebasan untuk mengutarakan pendapat (Djumiati, 2010).

Langkah-langkah dalam menerapkan model pembelajaran Make A Match menurut Aliputri (2018), yaitu: (1) Pertama-tama pengajar menyampaikan/mempresentasikan materi atau memberi tugas kepada siswa untuk mempelajari materi di rumah; (2) Pecahlah siswa menjadi 2 kelompok, misalnya kelompok A dan kelompok B. Mintalah siswa berhadap-hadapan; (3) Bagikan kartu pertanyaan kepada kelompok A dan kartu jawaban kepada kelompok B; (4) Sampaikan kepada siswa bahwa siswa harus mencari/mencocokkan kartu yang dipegang dengan kartu kelompok lain. Pengajar perlu menyampaikan batasan maksimum waktu yang diberikan kepada siswa; (5) Mintalah semua anggota kelompok A untuk mencari pasangannya di kelompok B. Jika siswa sudah menemukan pasangannya, mintalah siswa melaporkan diri kepada pengajar. Catatlah siswa pada kertas yang sudah dipersiapkan; (6) Jika waktu sudah habis, sampaikan kepada siswa bahwa waktu sudah habis. Bagi siswa yang belum menemukan pasangan, mintalah untuk berkumpul tersendiri; (7) Panggil satu pasangan untuk presentasi. Pasangan lain dan siswa yang tidak mendapat pasangan memperhatikan dan memberikan tanggapan apakah pasangan tersebut cocok atau tidak; (8) Pengajar memberikan konfirmasi tentang kebenaran pasangan tersebut; dan (9) Panggil pasangan berikutnya, begitu seterusnya sampai seluruh pasangan melakukan presentasi.

Kedua model pembelajaran akan menumbuhkan semangat siswa ketika dalam proses pembelajaran karena didalam pembelajaran siswa akan bersaing antar-kelompok untuk mendapatkan poin tertinggi. Karena selain mendapat nilai, kelompok yang memiliki poin tertinggi akan mendapatkan penghargaan di akhir pembelajaran. Oleh karenanya, untuk meningkatkan hasil belajar siswa dapat diterapkan model pembelajaran Teams Games Tournament dan Make A Match. 
Hasil belajar menurut Sudijono (2012), merupakan sebuah tindakan evaluasi yang dapat mengungkap aspek proses berpikir (cognitive domain) juga dapat mengungkap aspek kejiwaan lainnya, yaitu aspek nilai atau sikap (affective domain) dan aspek keterampilan (psychomotor domain) yang melekat pada diri setiap individu peserta didik. Artinya melalui hasil belajar dapat terungkap secara holistik penggambaran pencapaian siswa setelah melalui pembelajaran. Supratiknya (2012), mengemukakan bahwa hasil belajar yang menjadi objek penilaian kelas berupa kemampuan-kemampuan baru yang diperoleh siswa setelah mengikuti proses belajar-mengajar tentang mata pelajaran tertentu.

Alasan peneliti memilih model pembelajaran kooperatif tipe Teams Games Tournament dan Make A Match karena peneliti ingin membandingkan hasil belajar siswa pada kompetensi dasar Memahami Dasar-Dasar Sistem Jaringan Internet/Intranet menggunakan kedua model pembelajaran tersebut. Pemilihan model pembelajaran kooperatif tipe Teams Games Tournament dan Make A Match juga didasari hasil penelitian yang telah dilakukan oleh Astuti, Rizal, dan Nurdin (2014), yang menunjukkan: (1) Rata-rata hasil belajar ekonomi siswa yang pembelajarannya menggunakan model TGT lebih tinggi dibandingkan dengan model tipe MM; dan (2) Ada perbedaan efektivitas penggunaan model pembelajaran kooperatif yang diajar dengan tipe TGT dan model pembelajaran kooperatif tipe MM. Oleh karenanya, peneliti ingin menerapkan pembelajaran kooperatif tipe Teams Games Tournament dan Make A Match untuk melihat hasil belajar siswa kelas IX pada Kompetensi Dasar Memahami Dasar-Dasar Sistem Jaringan Internet/Intranet di SMP Negeri 5 Sungai Kakap.

\section{METODE}

Jenis penelitian termasuk penelitian kuantitatif dengan menggunakan metode eksperimen. Bentuk penelitian adalah quasi experimental design. Quasi exsperiment merupakan eksperimen yang memiliki perlakuan, pengukuran dampak, unit eksperimen namun tidak menggunakan penugasan acak untuk menciptakan perbandingan dalam rangka menyimpulkan perubahan yang disebabkan perlakuan. Rancangan yang digunakan dalam penelitian adalah 
nonequivalent control group design karena data yang didapat tidak lagi diacak untuk menentukan kelas eksperimen yang akan digunakan tetapi penentuan kelas eksperimen berdasarkan pertimbangan dari guru bidang studi dan peneliti. Adapun populasi dalam penelitian adalah seluruh siswa kelas IX SMP Negeri 5 Sungai Kakap. Penentuan sampel dalam penelitian menggunakan teknik sampling purposive. Adapun kelas yang menjadi sampel pada penelitian adalah kelas IX D yang berjumlah 28 siswa sebagai kelas eksperimen I dan IX C berjumlah 27 siswa sebagai kelas eksperimen II.

Teknik pengumpul data yang tepat digunakan adalah teknik pengukuran. Alat pengumpul data yang sesuai untuk digunakan dalam penelitian adalah tes. Tes digunakan untuk pengambilan data penelitian kuantitatif karena instrumen tes untuk mengukur kemampuan seseorang dalam bidang tertentu. Tes yang digunakan dalam penelitian adalah post test untuk mengukur kemampuan siswa. Tes yang diberikan kepada siswa sebelumnya sudah dilakukan uji validitas dan uji reliabilitas. Melalui tes pilihan ganda diharapkan siswa dapat memilih jawaban yang sesuai, penalaran, dan komunikasi dalam pemecahan masalah.

Data dianalisis dengan menggunakan analisis deskriptif dan analisis inferensial. Analisis deskriptif digunakan untuk menentukan rerata hitung (x), sedangkan analisis inferensial dilakukan untuk melakukan uji hipotesis. Sebelum uji hipotesis dilakukan, maka dilakukan terlebih dahulu uji prasyarat analisis yaitu uji normalitas dan uji homogenitas. Pengujian hipotesis dianalisis dengan menggunakan Independen Sampel T-Test.

\section{HASIL DAN PEMBAHASAN}

Berdasarkan hasil belajar siswa, dapat dilihat jumlah nilai yang diperoleh tiap siswa pada post test. Adapun rekapitulasi hasil post test siswa pada kelas yang menggunakan model Teams Games Tournament dan kelas yang menggunakan model Make A Match yang dihitung menggunakan program SPSS, dapat dilihat pada tabel berikut. 
Tabel 1 Rekapitulasi Hasil Post Test Siswa

\begin{tabular}{lccccc}
\hline & Mean & $\begin{array}{c}\text { Std. } \\
\text { Deviation }\end{array}$ & Minimum & Maximum \\
\hline $\begin{array}{l}\text { Teams Games } \\
\text { Tournament }\end{array}$ & 8 & 79,8929 & 9,35054 & 63,00 & 93,00 \\
\hline Make A Match & 7 & 84,5185 & 7,46464 & 66,00 & 96,00 \\
\hline
\end{tabular}

Berdasarkan Tabel 1, diketahui bahwa nilai terendah kelas yang menggunakan model Teams Games Tournament adalah 63 sedangkan nilai tertinggi pada kelas tersebut adalah 93. Sedangkan untuk nilai terendah yang diperoleh pada kelas yang menggunakan model Make A Match adalah 66 sedangkan nilai tertinggi pada kelas tersebut adalah 96. Dari nilai post test menunjukkan bahwa hasil belajar siswa pada kelas yang menggunakan model Team Games Tournament berbeda dengan kelas yang menggunakan model Make A Match, dengan rata-rata kelas yang menggunakan model Teams Games Tournament adalah 79,8929 dan rata-rata hasil belajar siswa yang menggunakan model Make A Match adalah 84,5185. Jika dilihat dari rata-rata kedua kelas dengan standar deviasi untuk kelas yang menggunakan model Teams Games Tournament sebesar 9,35054 dan standar deviasi kelas yang menggunakan model Make A Match sebesar 7,46464.

Berdasarkan standar deviasi, dapat dilihat bahwa hasil belajar siswa kelas yang menggunakan model Make A Match lebih homogen dari pada hasil belajar siswa kelas yang menggunakan model Teams Games Tournament. Sehingga standar deviasi untuk kelas yang menggunakan model Make A Match lebih kecil dari pada kelas yang menggunakan model Teams Games Tournament dan besarnya varians kedua kelas masing-masing untuk kelas yang menggunakan model Teams Games Tournament sebesar 87,433 sedangkan pada kelas yang menggunakan model Make A Match adalah 55,721.

Pengujian normalitas data diperlukan untuk mengetahui apakah data yang dianalisis berdistribusi normal dan juga berasal dari populasi yang normal pula. Kriteria yang digunakan yaitu data dikatakan normal apabila harga koofisien 
asymp.sign output kolmogrov-smirnov test > dari alpha yang ditentukan yaitu 5\% $(0,05)$. Hasil normalitas untuk data post test pada kelas yang menggunakan model Teams Games Tournament dan kelas yang menggunakan model Make A Match dihitung dengan menggunakan software SPSS dengan hasil perhitungan yang dapat dilihat pada tabel berikut.

Tabel 2 Hasil Uji Normalitas Post Test

\begin{tabular}{ccc}
\hline $\mathbf{N}$ & Teams Games Tournament & Make A Match \\
\hline Asymp. Sig. (2-tailed) & 0,064 & 0,194 \\
\hline
\end{tabular}

Pada Tabel 2, terlihat bahwa nilai sig untuk Teams Games Tournament sebesar 0,064 dan nilai sig untuk Make A Match sebesar 0,194. Dengan demikian, data model pembelajaran baik kelas yang menggunakan model Teams Games Tournament maupun kelas yang menggunakan model Make A Match berdistribusi normal karena nilai sig $>0,05$.

Pengujian homogenitas data diperlukan untuk mengetahui varians dari kelas sampel yang diteliti, apakah kedua sampel mempunyai varians yang sama (homogen) atau tidak. Kriteria yang digunakan yaitu jika nilai signifikansi < 0,05, maka dikatakan bahwa varian dari dua ataulebih kelompok populasi data adalah tidak sama sedangkan jika nilai signifikansi > 0,05, maka dikatakan bahwa varian dari dua atau lebih kelompok populasi data adalah sama atau homogen.

Setelah pengolahan data diperoleh, uji homogenitas dihitung dengan menggunakan bantuan software SPSS untuk kelas yang menggunakan model Teams Games Tournament dan kelas yang menggunakan model Make A Match, hasil dari perhitungan yang telah dilakukan dapat dilihat pada tabel berikut.

Tabel 3 Hasil Uji Homogenitas

\begin{tabular}{llllll}
\hline & & $\begin{array}{l}\text { Retribusi } \\
\text { Statistik }\end{array}$ & df1 & df2 & Sig. \\
\hline Nilai Siswa & Based on Mean & 0,808 & 1 & 53 & 0,373 \\
& $\begin{array}{l}\text { Based on Median } \\
\text { Based on Median and }\end{array}$ & 0,799 & 1 & 53 & 0,373 \\
& $\begin{array}{l}\text { with adjusted df } \\
\text { Based on trimmed mean }\end{array}$ & 0,807 & 1 & 53 & 0,373 \\
\hline
\end{tabular}


Tabel 3 menunjukkan bahwa nilai signifikansi sebesar 0,373>0,05, artinya data variabel hasil belajar berdasarkan variabel kelas eksperimen I dan kelas eksperimen II mempunyai varian yang sama atau homogen. Setelah data berdistribusi normal dan bersifat homogen, selanjutnya adalah penggunaan uji tindependen sampel $t$ test karena jumlah sampel $\mathrm{n}_{1} \neq \mathrm{n}_{2}$ dan kedua kedua variansnya homogen. Uji perbedaan dihitung dengan menggunakan software SPSS dengan hasil perhitungan yang dapat dilihat pada tabel berikut.

Tabel 4 Hasil Uji Perbedaan

\begin{tabular}{|c|c|c|c|c|c|c|}
\hline & & $\mathrm{F}$ & Sig. & $\mathrm{t}$ & Df & $\begin{array}{l}\text { Sig. (2- } \\
\text { tailed) }\end{array}$ \\
\hline \multirow[t]{2}{*}{$\begin{array}{l}\text { Nilai } \\
\text { Siswa }\end{array}$} & $\begin{array}{l}\text { Equal variances } \\
\text { assumed }\end{array}$ & 0,808 & 0,373 & $-2,023$ & 53 & 0,048 \\
\hline & $\begin{array}{l}\text { Equal variances not } \\
\text { assumed }\end{array}$ & & & $-2,031$ & 51,240 & 0,047 \\
\hline
\end{tabular}

Berdasarkan perhitungan yang telah dilakukan dengan menggunakan SPSS jumlah sig $=0,048<0,05$, maka $\mathrm{H}_{0}$ ditolak. Artinya pada taraf kepercayaan $5 \%$ disimpulkan bahwa terdapat perbedaan rata-rata setelah diterapkan model pembelajaran kooperatif tipe Teams Games Tournament dan tipe Make A Match terhadap hasil belajar siswa kelas IX pada kompetensi dasar Memahami DasarDasar Jaringan Internet/Intranet di SMP Negeri 5 Sungai Kakap. Berdasarkan perhitungan yang telah dilakukan dapat diketahui bahwa nilai rata-rata Make A Match lebih besar dibandingkan dengan nilai rata-rata Teams Games Tournament, dengan rata-rata nilai kelas Teams Games Tournament adalah 79,8929 dari nilai maksimal 93,00 dan standar deviasi sebesar 9,35 dan rata-rata nilai kelas Make A Match adalah 84,5185 dari nilai maksimal 96,00 dan standar deviasi sebesar 7,46.

Dari kedua hasil belajar tersebut dilakukan uji perbandingan rata-rata pada tahap akhir dengan menggunakan uji t. Dengan taraf signifikansi $\alpha=5 \% \mathrm{dan} d \mathrm{k}=$ 【(n)_1+n_2-2 $)=30+30-2=58$ diperoleh t_hitung $=4,9456$ dan t_tabel $=$ 2,001717. Karena $-\mathrm{t} \_$tabel $\leq \mathrm{t} \_$hitung $\leq \mathrm{t} \_$tabel, maka $\mathrm{H}_{0}$ ditolak. Artinya peserta didik yang menggunkan model pembelajaran Make A Match dan model pembelajaran Teams Games Tournament memiliki rata-rata yang tidak identik/berbeda. Maka dapat disimpulkan bahwa hasil belajar TIK peserta didik yang menggunakan 
model pembelajaran Make A Match lebih baik dari hasil belajar TIK peserta didik yang menggunakan model pembelajaran Teams Games Tournament.

Hasil penelitian tersebut sejalan dengan penelitian yang dilakukan oleh Nursupratiwi (2015), yang meperlihatkan bahwa hasil belajar peserta didik yang menggunakan model pembelajaran Make A Match pada pelajaran materi pokok Lingkaran kelas VIII di SMP Negeri 01 Toroh Grobogan diperoleh rata-rata kelas yaitu 68,80. Sedangkan hasil belajar peserta didik yang menggunakan model pembelajaran Teams Games Tournament pada pelajaran matematika materi pokok Lingkaran kelas VIII di SMP Negeri 01 Toroh Grobogan diperoleh rata-rata kelas yaitu 59,16 .

\section{SIMPULAN}

Berdasarkan hasil pengolahan data penelitian, secara umum dapat disimpulkan bahwa terdapat perbedaan hasil belajar siswa setelah diterapkannya pembelajaran TIK melalui model pembelajaran kooperatif tipe Teams Games Tournament dan model pembelajaran kooperatif tipe Make A Match pada kompetensi dasar memahami dasar-dasar sistem jaringan internet/intranet di SMP Negeri 5 Sungai Kakap.

Adapun kesimpulan untuk sub-sub masalah dalam penelitian adalah: (1) Rata-rata hasil belajar siswa setelah diterapkannya model pembelajaran kooperatif tipe Teams Games Tournament terhadap hasil belajar siswa kelas IX pada kompetensi dasar Memahami Dasar-Dasar Sistem Jaringan Internet/Intranet di SMP Negeri 5 Sungai Kakap sebesar 79,8929; (2) Rata-rata hasil belajar siswa setelah diterapkannya model pembelajaran kooperatif tipe Make A Match terhadap hasil belajar siswa kelas IX pada kompetensi dasar Memahami Dasar-Dasar Sistem Jaringan Internet/Intranet di SMP Negeri 5 Sungai Kakap sebesar 84,5185; dan (3) Terdapat perbedaan rata-rata setelah diterapkan model pembelajaran kooperatif tipe Teams Games Tournament dan tipe Make A Match terhadap hasil belajar siswa kelas IX pada kompetensi dasar Memahami Dasar-Dasar Jaringan Internet/Intranet di SMP Negeri 5 Sungai Kakap. 


\section{DAFTAR PUSTAKA}

Aliputri, D. H. 2018. Penerapan Model Pembelajaran Kooperatif Tipe Make A Match Berbantuan Kartu Bergambar untuk Meningkatkan Hasil Belajar Siswa. Jurnal Bidang Pendidikan Dasar (JBPD), 2(1): 70-77.

Astuti, H. W., Rizal, Y., \& Nurdin. 2018. Perbandingan Hasil Belajar Ekonomi Menggunakan Model TGT dan MM. Jurnal Edukasi Ekobis 6(5).

Djumiati. 2010. Model Pembelajaran Make a Match. Jurnal Kependidikan Dasar, 1(2): $70-77$.

Rochmanto, Y. 2015. Penerapan Model PembelajaranTGT (Team Games Tournament) pada Mata Pelajaran IPS Kelas VIII dengan Memanfaatkan Facebook sebagai Media Pembelajaran. Journal of Educational Social Studies, 4(1): 1-7.

Sudijono, A. 2012. Pengantar Evaluasi Pendidikan. Jakarta: PT. RajaGrafindoPersada.

Supratiknya, A. 2012. Penilaian Hasil Belajar dengan Teknik Nontes. Yogyakarta: Universitas Sanata Darma.

Supratiwi, N. 2015. Studi Komparasi Hasil Belajar Matematika Menggunakan Model Pembelajaran Make A Match dan Model Pembelajaran Teams Games Tournament (TGT) Pada Materi Pokok Kelas VIII SMP Negeri 01 Toroh Tahun Pelajaran 2014/2015. Skripsi Sarjana Pendidikan Pada Universitas Islam Negeri Walisongo Semarang: Tidak diterbitkan.

Suprijono, A. 2013. Cooperative Learning Teori dan Aplikasi PAIKEM. Yogyakarta: Pustaka Pelajar.

Susanna. 2017. Penerapan Teams Games Tournament (TGT) melalui Media Kartu Domino pada Materi Minyak Bumi Siswa Kelas XI MAN 4 Aceh Besar. Lantanida Journal, 5(2): 93-105.

Veloo, A., dkk. 2016. Using Cooperative Teams-Game-Tournament in 11 Religious School to Improve Mathematics Understanding and Communication. Malaysian Journal of Learning and Instruction, 13(2): 97123. 